\title{
Helene Cixous - Jacques Derrida, Veli
}

\section{Rosa Galli Pellegrini}

\section{(2) OpenEdition}

\section{Journals}

\section{Edizione digitale}

URL: http://journals.openedition.org/studifrancesi/35252

DOI: 10.4000/studifrancesi.35252

ISSN: 2421-5856

\section{Editore}

Rosenberg \& Sellier

\section{Edizione cartacea}

Data di pubblicazione: 1 novembre 2005

Paginazione: 453

ISSN: 0039-2944

\section{Notizia bibliografica digitale}

Rosa Galli Pellegrini, «Helene Cixous - Jacques Derrida, Veli», Studi Francesi [Online], 146 (XLIX | II) |

2005, online dal 30 novembre 2015, consultato il 18 avril 2021. URL: http://journals.openedition.org/ studifrancesi/35252 ; DOI: https://doi.org/10.4000/studifrancesi.35252

\section{Questo documento è stato generato automaticamente il 18 avril 2021.}

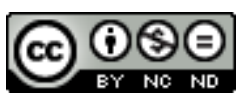

Studi Francesi è distribuita con Licenza Creative Commons Attribuzione - Non commerciale - Non opere derivate 4.0 Internazionale. 


\title{
Helene Cixous - Jacques Derrida, Veli
}

\author{
Rosa Galli Pellegrini
}

\section{NOTIZIA}

HELENE CIXOUS - JACQUES DERRIDA, Veli, con disegni di Ernest Pignon-Ernest, trad. di Monica Fiorini, Firenze, Alinea editrice, 2004, pp. 74.

1 Con questo titolo vengono qui raccolti e tradotti due testi, Sapere, di Hélène Cixous, e Un baco da seta. Punti di vista trapunti sull'altro velo, di Jacques Derrida. Nell'avantesto Si prega di inserire, è spiegata l'edizione congiunta dei due testi, apparsa nel 1997 sulla rivista Contretemps. 